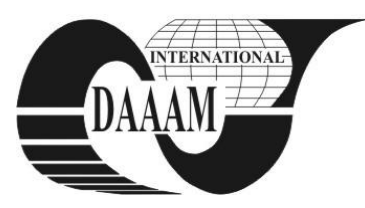

Annals of DAAAM for 2011 \& Proceedings of the 22nd International DAAAM Symposium, Volume 22, No. 1, ISSN 1726-9679 ISBN 978-3-901509-83-4, Editor B. Katalinic, Published by DAAAM International, Vienna, Austria, EU, 2011 Make Harmony between Technology and Nature, and Your Mind will Fly Free as a Bird Annals \& Proceedings of DAAAM International 2011

\title{
CHARACTERISTICS OF MANAGING OPERATIONAL BANKING RISK
}

\author{
IUGA, I[ulia] C[ristina] \& SOCOL, A[dela]
}

\begin{abstract}
The objective of this paper is to provide a global perspective of the operational risk from a banking societies' viewpoint. The paper presents the need of banks to managing operational risk. We study comparatively for a banking society the capital charge for covering the operational risk under the Basic Indicator Approach and under the Standardized Approach. We present a case study of implementing current capital requirements at the level of a Romanian banking society.

Key words: operational, banking, risk, capital adequacy
\end{abstract}

\section{INTRODUCTION}

We remark the specialized papers that present the empirical studies of the operational risk and its quantification (Chapelle, 2008). Chorafas (Chorafas, 2003) presents the five models advanced by the Basel Committee on Banking Supervision for computation of operational risk, on a double scale - expected amount of capital allocation, and complexity. ChavezDemoulin, Embrechts and Neslehova (2006) discuss some of the more recent stochastic methodology which may be useful towards the quantitative analysis of certain types of operational loss data.

Others authors provide both analytic results and extensive simulation studies of insurance mitigation for important basic policies (Peters, 2011). Within a marking-to-model framework, the research realized by Chateau (Chateau, 2009) computes the bank's capital charge for credit and operational risk of loan commitments at Basel-2 fixed audit date.

\section{MANAGING THE BANKING OPERATIONAL RISK}

Contemporary banks don't aim at eliminating the risks (an impossible approach in the present banking field), but they concentrate on learning the potential danger and the level of impact for the risks affecting their activity. We can say that adopting the Basel II Agreement brought a revolution in the operational risk field. This category of risk is taken into account for the first time in an international agreement for determining the banks' capital requirements.

Nowadays, in Romania all the active banking societies must apply the following procedures for managing the operational risk: Valuation procedures; Monitoring procedures and Risk decreasing procedures, either in the internal field, by correcting in time the determined errors and by introducing adequate technologies for processing and insuring the information security, or by transferring the risk to other domains of activity.

\section{QUANTIFYING OPERATIONAL BANKING RISK}

According to the New Basel II Agreement the banking companies must accomplish specific capital requirements regarding the total credit, market and operational risk.

The capital ratio is calculated using the definition of regulatory capital and risk-weighted assets and must be no lower than $8 \%$, according to the 40 article from the Basel II Agreement:

\section{Total Amount of Capital/Risk - Weighted Assets $\geq 8 \%$}

In the Basel II approach, average assets risk-weighted must include capital requirements for covering the operational risk.

The active banks in Romania must determine their capital necessary for covering the operational risk using one of the three means of quantification mentioned by the Basel II Agreement, assumed by the Capital Requirements Directive $\mathrm{CRD}$ and by the national legislation - the National Romanian Bank's regulation regarding the operational risk: the Basic Indicator Approach, the Standardized Approach and Advanced Measurement Approaches.

\section{APPROACHES PERMITTED FOR QUANTIFYING THE BANKING OPERATIONAL RISK IN ROMANIA}

\subsection{The Basic Indicator Approach (BIA)}

Banking societies must permanently have funds for covering the operational risk to which they are exposed. In the framework of the Base Indicator Approach calculating the capital required for covering the operational risk is done by applying the $15 \%$ quota upon a relevant indicator determined according to the methodology exposed below. The relevant indicator is calculated as an arithmetic average of the annual gross results of the bank's activity recorded by the credit institution in the last three ended financial exercises.

Banks using the Basic Indicator Approach must hold capital for operational risk equal to the average over the previous three years of a fixed percentage (denoted alpha) of positive annual gross income. When calculating the average, figures for any year in which annual gross income is negative or zero should be excluded from both the numerator and denominator. The charge may be expressed as follows:

$$
K_{B I A}=\left[\sum\left(G I_{1 \ldots N} \times \alpha\right)\right] / N,
$$

Where:

$K_{B I A}=$ the capital charge under the Basic Indicator Approach; GI = annual gross income, where positive, over the previous three years;

$\mathrm{N}=$ number of the previous three years for which gross income is positive;

$\alpha=15 \%$, which is set by the Committee.

In the Table no. 1, we present an abridgement from Income Statement of a bank, with the necessary lines of the calculus of the gross annual result and the capital charge under Basic Indicator Approach:

\begin{tabular}{|l|l|l||}
\hline \multicolumn{1}{||c|}{- RON (Romanian National Currency) } \\
\hline \multicolumn{1}{||c|}{ Year 2008 } & Year 2009 & Year 2010 \\
\hline \multicolumn{1}{||l|}{ Interest income and assimilated income } \\
\hline Interest expense and assimilated expense \\
\hline 915.877 .306 & 2.077 .290 .759 & 1.863 .650 .088 \\
\hline Income from shares and other variable income securities \\
\hline
\end{tabular}




\begin{tabular}{||l|l|l|}
\hline \hline 3.157 .561 & 741.544 & 740.491 \\
\hline Commission income & 395.608 .368 & 401.037 .329 \\
\hline 405.754 .932 & 42.552 .013 & 44.068 .748 \\
\hline Commission expense & 179.334 .490 & 127.158 .878 \\
\hline 43.167 .988 & 16.430 .581 & 18.024 .588 \\
\hline Net profit/(loss) from financial operations \\
\hline 23.313 .802 & 1.291 .950 .543 & 1.483 .668 .644 \\
\hline Other operating income \\
\hline 12.782 .848 \\
\hline GROSS RESULT FOR THE YEAR \\
\hline 1.001 .204 .722 \\
\hline Capital charge under BIA \\
\hline $188.841 .195,45$ \\
\hline
\end{tabular}

Tab. 1. The minimum necessary capital for the covering of the operational banking risk in the Basic Indicator Approach. Elements from INCOME STATEMENT

Because all three values of GI are strictly positive numbers, $\mathrm{N}$ will be equal to 3 . In this case, capital charge under BIA takes value:

$$
K_{B I A}=\left(\begin{array}{l}
1.001 .204 .722+ \\
1.291 .950543+ \\
1.483 .668644
\end{array}\right) X 0,15 / 3=188.841 .19,45 \mathrm{RON}
$$

So, in 2011, the minimum necessary capital for covering the operational risk under Basic Indicator Approach is of 188.841.195,45 RON. The banks dispose of the primary information for the determination of the requirement of capital concerning the operational risk, on the strength of Income Statement.

\subsection{The Standardized Approach}

In According to the Standardized Approach, banks' activities are divided into eight business lines. Within each business line, gross income is a broad indicator that serves as a proxy for the scale of business operations and thus the likely scale of operational risk exposure within each of these business lines.

We present the activity lines for the gross income of a banking society during 2008-2010 and we calculate the capital charge for the covering the operational risk under the Standardized Approach:

\begin{tabular}{|c|c|c|}
\hline \multicolumn{3}{|c|}{ Gross income GI } \\
\hline Year 2008 & Year 2009 & Year 2010 \\
\hline \multicolumn{3}{|c|}{ Corporate finance } \\
\hline$-484.482 .725,34$ & $-55.913 .670,15$ & $-51.308 .174,18$ \\
\hline \multicolumn{3}{|c|}{ Trading and sales } \\
\hline $225.778 .357,48$ & $43.870 .725,81$ & $67.510 .755,50$ \\
\hline \multicolumn{3}{|c|}{ Retail banking } \\
\hline 0 & 0 & 0 \\
\hline \multicolumn{3}{|c|}{ Commercial banking } \\
\hline $635.001 .630,30$ & $83.440 .400,07$ & $101.266 .133,25$ \\
\hline \multicolumn{3}{|c|}{ Payment and settlement } \\
\hline $89.370 .599,82$ & $13.763 .364,96$ & $16.202 .581,32$ \\
\hline \multicolumn{3}{|c|}{ Agency services } \\
\hline 0 & 0 & $1.350 .215,11$ \\
\hline \multicolumn{3}{|c|}{ Asset management } \\
\hline $4.703 .715,78$ & $860.210,31$ & 0 \\
\hline \multicolumn{3}{|c|}{ Retail brokerage } \\
\hline 0 & 0 & 0 \\
\hline
\end{tabular}

Tab. 2. Yearly gross income of a banking society, detailed on activity lines (RON)

The capital charge for each business line is calculated by multiplying gross income by a factor (denoted beta) assigned to that business line. The total capital charge is calculated as the three-year average of the simple summation of the regulatory capital charges across each of the business lines in each year.
The total capital charge may be expressed as:

$$
K_{T S A}=\left\{\sum_{\text {years } 1-3} \max \left[\Sigma\left(G I_{1-8} \times \beta_{1-8}\right), 0\right]\right\} / 3
$$

Where:

$\mathrm{K}_{\mathrm{TSA}}=$ the capital charge under the Standardized Approach $\mathrm{GI}_{1-8}=$ annual gross income in a given year, for each of the eight business lines

$\beta_{1-8}=\mathrm{a}$ fixed percentage, set by the Committee, relating the level of required capital to the level of the gross income for each of the eight business lines

The values of the betas are: Corporate finance $18 \%$, Trading and sales $18 \%$, Retail banking 12\%, Commercial banking 15\%, Payment and settlement 18\%, Agency services 15\%, Asset management $12 \%$, Retail brokerage $12 \%$.

The summation for each year, over all eight business lines will be:

\begin{tabular}{||c|c|c||}
\hline Year 2008 & Year 2009 & Year 2010 \\
\hline 65.334 .612 & 12.928 .961 & 21.225 .382 \\
\hline
\end{tabular}

Tab. 3. Capital request referring to the banking operational risk (RON)

Since all three values are positively, we obtain the following value for the capital charge under the Standardized Approach:

$K_{T S A}=\frac{65.334 .612+12.928 .961+21.225 .382}{3}=33.162 .985$

So, in 2011 , the minimum necessary capital banking studious society for the covering the operational risk under the Standardized Approach is of 33.162.985 RON. The same banking society had been studied through the Basic Indicator Approach of the banking operational risk, situation in which had been obtained a value for the capital request for covering the operational banking risk of 188.841.195,45 RON

\section{CONCLUSION}

We consider that the difference of capital between the two approaches, base and standard approach is considerable. In such a context, the banking societies should adapt the evidence and transactions recording system, so that it can apply the standard approach in quantifying the operational risk. This approach is also a starting point in implementing the most advanced shape of quantifying the operational banking risk - the advanced measurements.

\section{REFERENCES}

Chapelle, A., Crama, Y., Hubner, G., Peters, J.P. (2008), Practical methods for measuring and managing operational risk in the financial sector: A clinical study. Journal of Banking \& Finance, Vol. 32, Issue 6, 1049-1061, ISSN 0378-4266

Chateau, J.P.D. (2009). Marking-to-model credit and operational risks of loan commitments: A Basel-2 advanced internal ratings-based approach. International Review of Financial Analysis, Vol. 18, Issue 5, 260-270, ISSN 10575219

Chavez-Demoulin, V., Embrechts, P., Neslehova, J. (2006). Quantitative models for operational risk: Extremes, dependence and aggregation. Journal of Banking \& Finance, Vol. 30, Issue 10, 2635-2658, ISSN 0378-4266

Chorafas, D.N. (2003). Operational Risk Control with Basel II Basic Principles and Capital Requirements. Imprint Butterworth Heinemann, ISBN 978-0-7506-5909-3

Peters, G.W., Byrnes, A.D., Shevchenko P.V. (2011). Impact of insurance for operational risk: Is it worthwhile to insure or be insured for severe losses? Insurance: Mathematics and Economics, Vol. 48, Issue 2, 287-303, ISSN 0167-6687. 